\title{
O.В. Бочкарьова
}

Кафедра акушерства та гінекологї (зав. - проф. О.М. Юзько) ВДНЗ Украӥни

“Буковинський державний медичний університет”, м. Чернівці

\section{РОЛЬ ПОЛІМОРФІЗМУ ГЕНА БІЛКА ТЕПЛОВОГО ШОКУ 70-2 У РОЗВИТКУ ВУЛЬВОВАГІНІТІВ У ДІВЧАТ БУКОВИНИ}

Резюме. У даній науковій праці вперше провели аналіз A1267G поліморфізму гена HSP70-2 (id.: rs 1061581) у структурі хворих на вульвовагініти дівчат, оскільки поліморфізми генів HSP70 відіграють важливу роль у роботі імунної системи і можуть бути однією з важливих причин генетично зумовленої дисрегуляції запальної реакції, що дозволило представити наукову концепцію патогенетичних механізмів розвитку вульвовагініту.

Ключові слова: вульвовагініт, дівчата пубертатного періоду, поліморфізму гена HSP70-2.

Запальні процеси геніталій належать до числа найбільш поширених захворювань у дівчаток. Вони негативно впливають на стан здоров'я майбутньої жінки.

Особливе занепокоєння викликає стан репродуктивного здоров'я молоді, яке є невід'ємною складовою здоров'я нації в цілому і має стратегічне значення для забезпечення сталого розвитку суспільства. Наразі стан репродуктивного здоров'я нації знаходиться далеко за межами міжнародних стандартів і характеризується низьким рівнем народжуваності на тлі високого рівня розвитку основних загроз репродукції народонаселення - безпліддя, мертвонароджуваності, спонтанних абортів, вроджених вад розвитку, материнської, перинатальної і малюкової смертності. Проблеми, що виникають у сфері репродуктивного здоров'я, зумовлені передусім незадовільним соціальним становищем громадян, недостатньою увагою до ролі інституту сім’і, збереження традиційної культури взаємовідносин у сім'ї як основної складової суспільства [1-3].

У препубертатному віці найбільш розповсюджені неспецифічні вульвовагініти - їх частота становить 2,68-3,21 на 10 тис. дітей. Їм належить 68-93\% у структурі запальних захворювань геніталій у дітей та підлітків. Частота цієї патології серед інших гінекологічних захворювань у дівчат - 30-79\% (за даними деяких авторів навіть 8593\%) [2-4]. У структурі дитячих хвороб репродуктивної системи нейтрального періоду приблизно
70\% припадає на вульвовагініти [5, 6].

Актуальність вивчення патогенезу та методів терапії цього захворювання пов'язана насамперед 3 високою частотою рецидивів і хронізації, як вказують більшість авторів (60-70\% випадків), що може викликати зміни функціональної активності в системі гіпоталамус-гіпофіз-яєчники, сприяти значному збільшенню у цього контингенту дівчаток інших гінекологічних захворювань і спричинити в подальшому більш серйозні розлади основних функцій статевої системи дівчинки (менструальної, репродуктивної), а також призвести до порушень в ендокринній, нервовій, імунній та інших системах організму, погіршуючи прогноз відносно репродуктивної функції, що є соціальною і економічною проблемою[2, 6-8].

При дії на клітину пошкоджуючих факторів (зміни температури, гіпоксія, хімічні фактори, інфікування вірусом та ін.) відбувається інтенсифікація синтезу білків теплового шоку (HSP, від Heat Shock Proteins; по-іншому, білки стресу). Це може захистити клітку від пошкоджень і запобігти іiі загибель. Найбільш поширені HSP з Мг 70 000 (hsp70) та 90000 (hsp90) [6,7, 8 ].

Мета дослідження: удосконалити методи діагностики з метою оптимізації лікування та профілактики вульвовагінітів у дівчат для збереження репродуктивного потенціалу в майбутньому.

Матеріал $\boldsymbol{i}$ методи. Провести аналіз A1267G поліморфізму гена HSP70-2 (id.: 
rs 1061581) у структурі хворих на вульвовагініти дівчат-підлітків за допомогою молекулярно-генетичних та статистичних методів.

Результати дослідження та їх обговорення. Незважаючи на велику кількість досліджень, на сьогодні відсутні відомості участі генів HSP70 у патогенезі запальних захворювань органів малого тазу у дівчат-підлітків. Оскільки поліморфізми генів HSP70 відіграють важливу роль у роботі імунної системи і можуть бути однією 3 важливих причин генетично зумовленої дисрегуляції запальної відповіді, вважали за необхідне провести аналіз A1267G поліморфізму гена HSP70-2 (id.: rs1061581) у структурі хворих на вульвовагініти дівчат-підлітків та встановити ймовірність його пливу на продукцію про- і протизапальних цитокінів.

Встановили, що частота вияву “дикого” Gалеля у дівчат-підлітків дослідної та контрольної груп (табл. 1) є на 44,28\% і 50,0\% більшою, ніж “мінорного” А-алеля гена HSP70-2 (p<0,001). Відносна частота G-алеля та А-алеля у практично здорових дівчат та хворих на вульвовагініти статистично значимо не відрізнялась.

Відповідність розподілу генотипів 1267 $\mathrm{A} \rightarrow \mathrm{G}$ поліморфізму гена HSP70-2 до закону Ха-
рді-Вайнберга у групах дослідження перевіряли за допомогою тесту хі-квадрат із 1 ступенем свободи, без використання корекції Йетса (табл. 2). Розподіл генотипів поліморфізму аналізованого гена загалом відповідає очікуваному за рівновагою Hardy-Weinberg, що супроводжується надлишком гетерозиготності із негативним коефіцієнтом інбридингу на тлі відсутньої статистично значимої різниці між показниками очікуваної та фактичної гетерозиготності (p>0,05).

Аналіз ко-домінантної моделі успадкування засвідчив вірогідну перевагу частоти AG- та GGгенотипів гена HSP70-2 у осіб дослідної групи над АА-генотипом у 17,5 і 16,5 разів $\left(\chi^{2}=40,01\right.$ i $\left.\chi^{2}=36,61, \mathrm{p}<0,001\right)$, без суттєвий відмінностей у частоті вияву проміжного генотипу і диких гомозигот як серед хворих, так і у контролі $(\mathrm{p}>0,05)$ (табл. 3). Інформаційний критерій Айкайке (AIC) для даної моделі становить 14,39. Частоти генотипів $1267 \mathrm{~A} \rightarrow \mathrm{G}$ поліморфізму гена HSP70-2 у дівчат із вульвовагінітами та практично здорових вірогідно не відрізнялись.

Серед домінантної, рецесивної, наддомінантної та адитивної моделей успадкування (табл. 4), ми вибрали найкращу (найдієвішу) із найнижчим інформаційним критерієм Айкайке (AIC). Такою

Таблиця 1

Частоти алелей 1267 A $\rightarrow$ G поліморфізму гена HSP70-2 у дівчат, хворих на вульвовагініти

\begin{tabular}{|l|l|c|c|c|c|}
\hline № & $\begin{array}{l}\text { Групи } \\
\text { досліджень }\end{array}$ & $\begin{array}{c}\text { А алель, } \\
\mathrm{n}(\%)\end{array}$ & $\begin{array}{c}\mathrm{G} \text { алель, } \\
\mathrm{n}(\%)\end{array}$ & $\begin{array}{c}\mathrm{BW} \\
{[95 \% \mathrm{CI}]}\end{array}$ & $\chi^{2} \mathrm{p}$ \\
\hline 1 & $\begin{array}{l}\text { Дослідна група, } \mathrm{n}=140 \\
(70,0 \%)\end{array}$ & $39(27,86)$ & $101(72,14)$ & $\begin{array}{c}6,71[3,98- \\
11,31]\end{array}$ & $\begin{array}{c}\chi^{2}=54,91 \\
\mathrm{p}<0,001\end{array}$ \\
\hline 2 & $\begin{array}{l}\text { Контрольна група, } \\
\mathrm{n}=60(30,0 \%)\end{array}$ & $15(25,0)$ & $45(75,0)$ & $\begin{array}{c}9,0[3,94- \\
20,57]\end{array}$ & $\begin{array}{c}\chi^{2}=30,0 \\
\mathrm{p}<0,001\end{array}$ \\
\hline 3 & $\chi^{2} \mathrm{p}$ & $\begin{array}{c}\chi^{2}<1,0 \\
\mathrm{p}>0,05\end{array}$ & $\chi^{2}<1,0 \mathrm{p}>0,05$ & - & - \\
\hline 4 & Загалом, $\mathrm{n}=200(\%)$ & $54(27,0)$ & $146(73,0)$ & $\begin{array}{c}7,31[4,70- \\
11,37]\end{array}$ & $\begin{array}{c}\chi^{2}=84,64 \\
\mathrm{p}<0,001\end{array}$ \\
\hline
\end{tabular}

Примітки: ВШ - відношення шансів; n (\%) - абсолютна (відносна) кількість алелей

Таблицяя 2

Коефіцієнт інбридингу $1267 \mathrm{~A} \rightarrow \mathrm{G}$ поліморфізму гена HSP70-2 у дівчат, хворих на вульвовагініти

\begin{tabular}{|c|c|c|c|c|c|c|c|c|c|}
\hline \multirow{2}{*}{ Групи } & \multicolumn{2}{|c|}{ Алелі, n (\%) } & \multirow[b]{2}{*}{$\mathrm{P}_{\mathrm{A}}$} & \multirow[b]{2}{*}{$\mathrm{P}_{\mathrm{G}}$} & \multirow{2}{*}{$\mathrm{H}_{\mathrm{O}}$} & \multirow{2}{*}{$\mathrm{H}_{\mathrm{E}}$} & \multirow{2}{*}{$\mathrm{F}$} & \multirow[b]{2}{*}{$\chi^{2}$} & \multirow[b]{2}{*}{$P$} \\
\hline & A & $\mathrm{G}$ & & & & & & & \\
\hline $\begin{array}{l}\text { Дослідна група, } \\
\text { n=140 }\end{array}$ & $\begin{array}{c}39 \\
(27,86)\end{array}$ & $\begin{array}{c}101 \\
(72,14)\end{array}$ & 0,28 & 0,72 & 0,50 & 0,41 & $-0,24$ & 1,63 & $>0,05$ \\
\hline $\begin{array}{l}\text { Контроль- } \\
\text { нагрупа, n=60 }\end{array}$ & $15(25,0)$ & $45(75,0)$ & 0,25 & 0,75 & 0,50 & 0,38 & $-0,33$ & 2,92 & $>0,05$ \\
\hline Всього, $\mathrm{n}=200$ & $54(27,0)$ & $\begin{array}{c}146 \\
(73,0)\end{array}$ & 0,27 & 0,73 & 0,50 & 0,39 & $-0,27$ & 2,45 & $>0,05$ \\
\hline
\end{tabular}

Примітки: 1. $\mathrm{P}_{\mathrm{A}}$ - відносна частота Аалеля; $\mathrm{P}_{\mathrm{G}}$ - відносна частота Салеля. 2. $\mathrm{H}_{0}$ - фактична гетерозиготність; $\mathrm{H}_{\mathrm{E}}$ - очікувана гетерозиготність; F - коефіцієнт інбридингу. 3. $\chi^{2} \mathrm{p}$ - критерій справедливості “нульової” гіпотези між фактичною і очікуваною гетерозиготністю. 4. n (\%) - кількість (відсоток) спостережень 
Частоти генотипів 1267 A $\rightarrow$ G поліморфізму гена HSP70-2у дівчат, хворих на вульвовагініти та практично здорових

\begin{tabular}{|c|c|c|c|c|c|c|}
\hline \multirow[b]{2}{*}{ № } & \multirow{2}{*}{\multicolumn{2}{|c|}{$\begin{array}{l}\text { Генотипи гена } \\
\text { HSP70-2 }\end{array}$}} & \multicolumn{3}{|c|}{ Групи дослідження, n (\%) } & \multirow[b]{2}{*}{$\begin{array}{l}\chi^{2} \\
\mathrm{p}\end{array}$} \\
\hline & & & $\begin{array}{c}\text { Хворі, } \\
\mathrm{n}=70(\%)\end{array}$ & $\begin{array}{c}\text { Контроль, } \\
\mathrm{n}=30(\%)\end{array}$ & ВШ $[95 \% \mathrm{CI}]$ & \\
\hline 1 & \multicolumn{2}{|c|}{$\begin{array}{l}\text { АА-генотип, } \\
\mathrm{n}=2(\%)\end{array}$} & $2(2,86)$ & 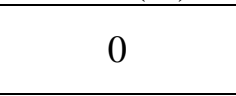 & - & - \\
\hline 2 & \multicolumn{2}{|c|}{$\begin{array}{l}\text { AG-генотип, n=50 } \\
(\%)\end{array}$} & $35(50,0)$ & $15(50,0)$ & $1,0[0,43-2,35]$ & $\begin{array}{l}\chi^{2}<1,0 \\
p>0,05\end{array}$ \\
\hline 3 & \multicolumn{2}{|c|}{ GG-генотип,n=48(\%) } & $33(47,14)$ & $15(50,0)$ & $0,89[0,38-2,10]$ & $\begin{array}{l}\chi^{2}<1,0 \\
p>0,05\end{array}$ \\
\hline 4 & \multirow{3}{*}{$\begin{array}{l}\chi \\
2 \\
p\end{array}$} & $\begin{array}{l}\text { AА-генотип про- } \\
\text { тии AG }\end{array}$ & $\begin{array}{c}\chi^{2}=40,01 \\
p<0,001\end{array}$ & - & - & 1 \\
\hline 5 & & $\begin{array}{l}\text { AА-генотип про- } \\
\text { тии GG }\end{array}$ & $\begin{array}{c}\chi^{2}=36,61 p<0,00 \\
1\end{array}$ & - & - & - \\
\hline 6 & & $\begin{array}{l}\text { AG-генотип про- } \\
\text { тии GG }\end{array}$ & $\chi^{2}<1,0 p>0,05$ & $\chi^{2}<1,0 p>0,05$ & - & - \\
\hline
\end{tabular}

Примітки: ВШ - відношення шансів; $\mathrm{n}$ - абсолютна кількість

Таблиия 4

Моделі успадкування вульвовагінітів у дівчат з урахуванням

$1267 \mathrm{~A} \rightarrow \mathrm{G}$ поліморфізму гена HSP70-2

\begin{tabular}{|c|c|c|c|c|c|}
\hline Генотип & Контроль, n (\%) & Випадок, n (\%) & ВШ $[95 \% \mathrm{CI}]$ & $\mathrm{p}$ & AIC \\
\hline \multicolumn{6}{|c|}{ Домінантна модель } \\
\hline GG & $15(50,0)$ & $33(47,14)$ & 1,0 & \multirow{2}{*}{0,79} & \multirow{2}{*}{13,78} \\
\hline $\mathrm{Ga}+\mathrm{aa}$ & $15(50,0)$ & $37(52,9)$ & $1,12[0,47-2,65]$ & & \\
\hline \multicolumn{6}{|c|}{ Рецесивна модель } \\
\hline $\mathrm{GG}+\mathrm{Ga}$ & $30(100,0)$ & $68(97,1)$ & 1,0 & \multirow{2}{*}{1,0} & \multirow{2}{*}{12,4} \\
\hline aa & 0 & $2(2,86)$ & - & & \\
\hline \multicolumn{6}{|c|}{ Наддомінантна модель } \\
\hline GG+aa & $15(50,0)$ & $35(50,0)$ & 1,0 & \multirow{2}{*}{1,0} & \multirow{2}{*}{13,85} \\
\hline $\mathrm{Ga}$ & $15(50,0)$ & $35(50,0)$ & $1[0,42-2,36]$ & & \\
\hline \multicolumn{6}{|c|}{ Аддитивна модель } \\
\hline GG & $15(50,0)$ & $33(47,14)$ & 1,0 & \multirow{2}{*}{0,63} & \multirow{2}{*}{13,61} \\
\hline $2 \mathrm{aa}+\mathrm{Ga}$ & $15(50,0)$ & $39(55,71)$ & $1,22[0,55-2,77]$ & & \\
\hline
\end{tabular}

Примітки: ВШ - відношення шансів; АІС - критерій Айкайке

стала рецесивна модель, для якої інформаційний критерій Айкайке становив 12,4. Отримані дані засвідчують, що вульвагініти у дівчат успадковуються як рецесивна ознака, яка фенотипово (клінічно) здатна проявитись тільки за певних, сприятливих для цього, умов.

Популяційний та расовий аналіз (табл. 5) засвідчив, що частота мінорного АА-генотипу гена HSP70-2 серед обстежених нами осіб (нуль у контролі, 2,86\% - серед хворих) є дещо нижчою, ніж у середньому для європеоїдних популяцій, засвідчуючи високу гетерогенність та неоднорідність популяцій за поліморфним локусом, у т.ч з урахуванням нозології, що однак не відрізнялось вірогідно загалом за алельним розподілом і відповідало європеоїдній $\operatorname{paci}\left(\mathrm{P}_{\mathrm{A}}=0,25-0,28\right.$ проти $\mathrm{P}_{\mathrm{A}}=0,33-0,71$ $\operatorname{taP}_{\mathrm{G}}=0,72-0,75$ проти $\left.\mathrm{P}_{\mathrm{G}}=0,67-0,87\right)$. При цьому час- тота А-алеля в на-ших дослідженнях перевищує таку в афро-американській популяції $\left(\mathrm{P}_{\mathrm{A}}=0,25-0,28\right.$ проти $\left.\mathrm{P}_{\mathrm{A}}=0-0,13\right)$, натомість $є$ вірогідно нижчою, ніж у азіатів $\left(\mathrm{P}_{\mathrm{A}}=0,44-0,48, \mathrm{p}<0,05\right)$ відповідно.

Таким чином, мутація у 1267 позиції промоторної зони гена HSP70-2 трапляється загалом у 2,86\% випадків. Розподіл A- i G-алелей A-1267 Gполіморфізму гена HSP70-2 засвідчує відносну однорідність розподілу у обстеженій популяції дівчат-підлітків Північної Буковини із переважанням дикого Gалеля як у контролі $(75,0 \%)$, так і серед хворих на вульвовагініти $(72,14 \%)$.Ризик появи вульвовагінітув популяції із урахуванням генетичної складової гена HSP70-2 наведено у таблиці 6. Встановили, що генотипи та алелі аналізованого гена не є додатковими чинниками ризику запалення вульви та вагіни у дівчат. 
Таблиия 5

Популяційні та расові відмінності частот генотипів, алелей1267 A $\rightarrow \mathrm{G}$ поліморфізму гена HSP70-2у порівняльному аспекті

\begin{tabular}{|l|c|c|c|c|c|}
\hline Раси, популяції & $\begin{array}{c}\text { АА-гено- } \\
\text { тип, \% }\end{array}$ & $\begin{array}{c}\text { AG-гено- } \\
\text { тип, \% }\end{array}$ & $\begin{array}{c}\text { GG-гено- } \\
\text { тип, \% }\end{array}$ & А-алель & G-алель \\
\hline $\begin{array}{l}\text { Отримані нами ре- } \\
\text { зультати (Північна Бу- } \\
\text { ковина) }\end{array}$ & $0-0,03$ & 0,50 & $0,47-0,50$ & $0,25-0,28$ & $0,72-0,75$ \\
\hline $\begin{array}{l}\text { Европеоїдна раса(ка- } \\
\text { вказіаниі) }\end{array}$ & $0,14-0,53$ & $0,38-0,45$ & $0,11-0,48$ & $0,33-0,71$ & $0,67-0,87$ \\
\hline $\begin{array}{l}\text { Екваторіальна раса } \\
\text { (суб-сахараїдальна } \\
\text { Африка, афро-амери- } \\
\text { канці) }\end{array}$ & $0-0,14$ & $0-0,27$ & $0,73-1,0$ & $0-0,13$ & $0,87-1,0$ \\
\hline Іспанці (Ніsрапіс) & 0,14 & 0,38 & 0,48 & 0,33 & 0,67 \\
\hline Мексиканці & $0,05-0,18$ & $0,58-0,69$ & $0,23-0,24$ & $0,44-0,48$ & $0,52-0,56$ \\
\hline Азіатська раса & 0,18 & 0,59 & 0,23 & 0,48 & 0,52 \\
\hline
\end{tabular}

Таблиия 6

Генотипи алельних варіантів гена HSP70-2 як фактори ризику появи вульвовагініту в дівчат у популяції загалом

\begin{tabular}{|l|c|c|c|c|c|}
\hline \multirow{2}{*}{ Показники } & \multicolumn{5}{|c|}{ Потенційний фактор ризику } \\
\cline { 2 - 6 } & $\begin{array}{c}\text { АА-гено- } \\
\text { тиП }\end{array}$ & АG-генотип & GG-генотип & А-алель & G-алель \\
\hline ПАР/ ЗАР & 0,005 & 0 & 0,03 & $-0,03$ & 0,03 \\
\hline ПВідР/ЗВідР & 0,14 & 0 & 0,06 & $-0,11$ & 0,04 \\
\hline $\mathrm{BiдP}$ & 0,86 & 1,0 & 0,94 & 1,11 & 0,96 \\
\hline $\mathrm{BP}$ & 0,86 & 1,0 & 0,94 & 1,11 & 0,96 \\
\hline $\mathrm{BШ}$ & 0,85 & 1,0 & 0,89 & 1,16 & 0,86 \\
\hline $95 \%$ ДІВР & $0,08-9,10$ & $0,65-1,53$ & $0,61-1,46$ & $0,67-1,86$ & $0,80-1,15$ \\
\hline $95 \%$ ДІ ВШ & $0,07-9,78$ & $0,43-2,35$ & $0,38-2,10$ & $0,58-2,31$ & $0,43-1,72$ \\
\hline $\mathrm{p}$ & $>0,05$ & $>0,05$ & $>0,05$ & $>0,05$ & $>0,05$ \\
\hline
\end{tabular}

Примітки: 1. ПАР / ЗАР - підвищення / зменшення абсолютного ризику; 2. ПВідР / ЗВідР - підвищення / зменшення відносного ризику; 3. ВідР - відносний ризик; 4. ВР - відношення ризиків; 5. ВШ - відношення шансів; 6 . 95\%ДІВР,ВШ - довірчі інтервали відношення ризиків (ВР), шансів (ВШ)

Висновки. 1. Серед хворих на вульвовагініти дівчат-підлітків гомозиготна однонуклеотидна заміна аденіну (A) на гуанін (G) у позиції 1267 промоторної зони 6-ї хромосоми $(\mathrm{CAG} \rightarrow \mathrm{CAA})$ гена HSP70-2 (id.: rs1061581) трапляється у 2,86\% випадків, за відсутності такої у групі контролю. За характером алельного розподілу $1267 \mathrm{G}>$ Аполіморфізму гена HSP70-2 домінує дикий G алель над А алелем: серед хворих - у 2,59 рази (72,14\% проти $\left.27,86 \%, \chi^{2}=54,91, \mathrm{p}<0,001\right)$, серед здорових - у 3 рази ( $75 \%$ проти $\left.25 \%, \chi^{2}=30,0, p<0,001\right)$ без вірогідних змін коефіцієнта інбридингу, що зага- лом не порушує очікуваної популяційної рівноваги Hardy-Weinberg. 2. Дикий G алель (AG-, GGгенотипи) гена HSP70-2 виявлено у кожного другого підлітка в популяції (50\% і 47,14\% - у дослідній групі, 50\% - у контролі). Мутантний АА-генотип серед дівчат-підлітків Північної Буковини, хворих на вульвовагініти, наявний із частотою $\mathrm{P}_{\mathrm{A}}=0,03$, і відсутній серед здорових. Аналіз моделей успадкування засвідчив, що вульвагініти у дівчат успадковуються як рецесивна ознака (критерій Айкайке $\mathrm{AIC}=12,4)$, що здатна фенотипово (у т.ч. клінічно) проявитись тільки за певних умов.

\section{Список використаної літератури}

1. Білоченко А.М. Клініко-патогенетичне обтрунтування лікування неспецифічних вульвовагінітів у дівчаток препубертатного віку: автореф. дис. на здобуття наук. ступеня канд. мед. наук: спеи. 14.01.01 “Акушерство та гінекологія" / А.М. Білоченко. - К., 2008. - 22 с. 2. Вдовиченко Ю.П. Сучасні аспекти 
профілактики і лікування вульвовагініту змішаного генезу / Ю.П. Вдовиченко, П.Н. Баскаков, К.Н. Масленников // Здоров'я жінки. - 2009. - № 5 (41). - С. 16-17. 3. Кира Е.Ф. Неспецифический вагинит и его влияние на репродуктивное здоровье женщчины / Е.Ф. Кира, С.З. Муслимова // Пробл. репродукции. - 2008. - № 5. - С. 8-13. 4. Лечение вульвовагинитов и вагинозов: клинико-лабораторная эффективность / В.Н. Прилепская, Е.А. Межевитинова, П.Р. Абакарова [и др.] // Гинеколог. - 2013. - T. 15, № 4. - С. 4-9. 5. Пирогова В.І. Репродуктивне здоров'я підлітків: сочіально-медичні аспекти / В.І. Пирогова, О.Р. Цьолко // Медична газета “Здоров’я України”. - 2014. - № 4 (16). - C. 8-9. 6. HSP90 as autoantigen at dilated cardiomiopathy / I. Kroupskaya, O. Vigontina, S. Mandryk [et al.] // Molecular mechanism of cellular signalling: 6-th Parnas Conference (30-th may 2007, Krakow). - 2-nd june, 2007: Abstracts. - Krakow, 2007. - P. 46. 7. Stricker T. Vulvovaginitis in prepubertal girls / T. Stricker, F. Navratil, F.H. Sennhauser // Arch. Dis. Child. - 2003. - Vol. 88, № 4. - P. 324-326. 8. Vulvovaginitis in young girls / A. Olejek, S. Kellas-Sleczka, I. Kozak-Darmas [et al.] // Ginekol. Pol. - 2009. - Vol. 80, № 12. - P. $931-934$.

\section{РОЛЬ ПОЛИМОРФИЗМА ГЕНА БЕЛКОВ ТЕПЛОВОГО ШОКА 70-2 В РАЗВИТИИ ВУ- ЛЬВОВАГИНИТА У ДЕВУШЕК БУКОВИНЫ Резюме. В данной научной работе впервые про- \\ THE ROLE OF POLYMORPHISM OF HEAT SHOCK PROTEIN 70-2 GENE IN THE DEVEL- OPMENT OF VULVOVAGINITIS IN GIRLS OF BUKOVYNA REGION} вели анализ A1267G полиморфизма гена HSP70-2 (id.: rs 1061581) в структуре больных вульвовагинитом девушек, поскольку полиморфизм генов HSP70 играет важную роль в работе иммунной системы и может быть одной из важных причин генетически обусловленной дисрегуляции воспалительной реакции, что позволило представить научную концепцию патогенетических механизмов развития вульвовагинита.

Ключевые слова: вульвовагинит, девушки пубертатного периода, полиморфизма гена HSP70-2

Abstract. The paper presents analysis of A1267G polymorphism of HSP70-2 (id.: rs1061581) gene in the structure of sickness of girls suffering from vulvovaginitis. Polymorphism of HSP70 genes plays very important role in working of the immune system. It can be one of the important reasons of the genetically-provoked disregulation of inflammatory reaction. This will enable to present the scientific conception of pathophysiologic mechanisms of the development of vulvovaginitis.

Key words: vulvovaginitis, girls of puberty age, polymorphism of HSP70-2 gene.

Higher State Educational Institution of Ukraine "Bukovinian State Medical University" (Chernivtsi)

Надійшла 12.09.2016 p. Рецензент - проф. Кравченко О.В. (Чернівці) 